and the epicentral distance has been calculated to be provisionally $2,690 \mathrm{~km}$. On. September 18 an carthquake was reported as having had its epicentre approximately 50 miles from Vienna. This shock damaged nearly all the buildings in the small village near the epicentre, and two people are reported killed. On September 20 several earth tremors wero experienced in Greece. Early in the day sovero shocks rocked the town of Patras, and much apprehension was caused, though thero appears to have been no resultant damage or loss of life. Shocks were felt also in several parts of the Peloponnesus, including Pyrgos, though here also no damage is reported. Minor tremors are relatively common in Greece, though shocks such as the one of April 22, 1928, which partly destroyed Corinth, are not so frequent. The last severe earthquake in Greece was probably that of July 20,1938 , which did damage at Scala Oropos and adjacent villages.

\section{Protection of Wild Birds}

We understand that the Royal Society for tho Protection of Birds has under consideration the drafting of a Bill to amend and consolidate the existing Acts for the protection of wild birds. Such a measure is highly desirable in viow of the com. plexity of the present laws dealing with wild birds. The general lines upon which now legislation should proceed is indicated by certain resolutions drawn up by representatives of the County Councils Association and of municipal corporations, and referred to in the report for 1938 of the Royal Society for the Protection of Birds: (1) that as the complexity of the existing law had led to difficulties in administration, there was, in the opinion of the Conference, a strong case for consolidation and simplification; (2) that protection should be afforded to all wild birds, their nests and eggs, throughout tho wholo year, with specific exemptions which should bo the subject of further discussion; (3) that meantime the Home Office be asked for its views on the matter.

As earlier attempts have shown, it is no easy matter to draft a Bird Protection Bill which is simple, affords all the protection required, and at the same time avoids the danger of opposition from interested persons who may block its passage through Parliament. But with good will and a willingness to compromise on points not vital to the essential interests of wild birds, it should be possible to draft a Bill which would commend itself to reasonablo opinion and obtain the assent of Parliament. On the other hand, possible compotition between Bills drafted by different bodies, such as for example the Royal Society for the Protection of Birds, the Scottish Society for the Protection of Birds, and perhaps the Home Office, should not be allowed to obscure the need and demand for new and simplified legislation, or, when conditions are more favourable, to delay its speedy passage to the Statute Book.

\section{Value of Fruit Juices}

THE possibility of cessation or restriction of supplies of citrus fruits or other fresh fruit juices from abroad makes some recent work carried out at the Long Ashton Research Station, Bristol, of particular value at the present time (Long Ashton, Ann. Rept. 1938). Canned black currant juice would appear to be of special importance. It has a high content of both vitamin $C$ and iron, and has proved extremely useful in cases of ulceration of the stomach and duodenum or hyperacidity. Similarly, apple juice has been successfully used in the treatment of pink discaso (erythrocdema). Information obtained from Switzerland and Germany supports the view of the medical significance of fruit juices, claims being made that they are of benefit in other diseases such as diabetes, inflammation of the lungs or kidneys. The writer suggests that closer co-operation with the medical profession in England is desirable, in order that the true facts and significance regarding the use of fruit juices should be discovered and the danger of any false claims be avoided.

\section{Ordnance Survey Plans}

Is a paper prepared for the British Association meeting at Dundee, but not delivered, Brigadier A. B. Clough outlined the recommendations of the report of the Committee appointed in May 1935 to consider the revision, scales, styles, etc., of Ordnance Survey maps. The recommendations may be noted even if delay must now ensue in the fulfilment of some. The principal points aro those: (I) that no changes be mado in the scales of existing maps ; (2) that the large. scale maps be rearranged so as to form a single national series instead of thirty-nino separato county series; (3) that the revision of the large-scale plans be a continuous rather than a periodic process; (4) that a new series of maps be introduced on a scale of 1 to 25,000 ; (5) that a grid be superimposed on all Ordnance maps. Several subsidiary and consequential recommendations follow, namely, that all large-scale plans should be square, that each 1 to 2,500 plan should cover 1 square kilometro of country, and that the metre should be the unit of measurement for the grid. It is also suggested that additional contours should be added to the six-inch map, and that the practice of publishing archæological maps should be continued.

\section{Research in Freshwater Biology}

The seventh annual report for the year ending March 31, 1939, shows that the Freshwater Biological Association of the British Empire is flourishing. The director, Dr. E. B. Worthington, in his roview and forecast, states that in last year's roport it was forecast that the year now under review would see the launching of new ventures by the Association, building on the foundation laid down during the previous seven years of the Association's history. Of these now developments, three are of primary importance. First, the investigation of the bacteria of fresh water, financed by the Department of Scientific and Industrial Research, has started and the changes in the bacterial flora of Windermere and other waters have now been followed through nearly a whole annual cycle. Secondly, the investigation of 